\title{
Diversity and Antimicrobial Properties of Lactic Acid Bacteria Isolated from Rhizosphere of Olive Trees and Desert Truffles of Tunisia
}

\author{
Imene Fhoula, Afef Najjari, Yousra Turki, Sana Jaballah, \\ Abdelatif Boudabous, and Hadda Ouzari
}

Université de Tunis El Manar, Faculté des Science de Tunis, LR03ES03 Laboratoire Microorganismes et Biomolécules Actives, 2092 Tunis, Tunisia

Correspondence should be addressed to Hadda Ouzari; imene.ouzari@fst.rnu.tn

Received 30 April 2013; Revised 30 July 2013; Accepted 10 August 2013

Academic Editor: George Tsiamis

Copyright (C) 2013 Imene Fhoula et al. This is an open access article distributed under the Creative Commons Attribution License, which permits unrestricted use, distribution, and reproduction in any medium, provided the original work is properly cited.

\begin{abstract}
A total of 119 lactic acid bacteria (LAB) were isolated, by culture-dependant method, from rhizosphere samples of olive trees and desert truffles and evaluated for different biotechnological properties. Using the variability of the intergenic spacer 16S-23S and 16S rRNA gene sequences, the isolates were identified as the genera Lactococcus, Pediococcus, Lactobacillus, Weissella, and Enterococcus. All the strains showed proteolytic activity with variable rates $42 \%$ were EPS producers, while only $10 \%$ showed the ability to grow in $9 \% \mathrm{NaCl}$. In addition, a low rate of antibiotic resistance was detected among rhizospheric enterococci. Furthermore, a strong antibacterial activity against plant and/or pathogenic bacteria of Stenotrophomonas maltophilia, Pantoea agglomerans, Pseudomonas savastanoi, the food-borne Staphylococcus aureus, and Listeria monocytogenes was recorded. Antifungal activity evaluation showed that Botrytis cinerea was the most inhibited fungus followed by Penicillium expansum, Verticillium dahliae, and Aspergillus niger. Most of the active strains belonged to the genera Enterococcus and Weissella. This study led to suggest that environmental-derived LAB strains could be selected for technological application to control pathogenic bacteria and to protect food safety from postharvest deleterious microbiota.
\end{abstract}

\section{Introduction}

Given the world's growing demand for food, more attention is needed for food preservation, postharvest, and agricultural product preservation from different harmful factors such as the contamination caused by microbial spoilage and toxic metabolites produced by yeast, mold, and/or bacteria [1,2], as well as the extensive use of synthetic chemicals and pesticides in food and agriculture. These factors may pose a health risk for human and animals and affect the ecological equilibrium of the environment [3].

Therefore, there is growing interest to establish alternative bioproducts to replace chemicals and toxic pesticides. For this purpose, using bacteria or natural compounds which exhibit the same inhibitory effect on phytopathogenic and spoilage microbes was not only shown to be efficient in storage life extension and nutritive and safety value retention, of food products but also the environment safeguarding $[4,5]$. Such bacteria are known by "biological control agents" [6]

Lactic acid bacteria form an ecologically heterogeneous group of Gram-positive bacteria, nonspore forming, immobile, and catalase negative, that excretes lactic acid as major end product and generally recognized as safe (GRAS) organisms [7]. They are also selected as probiotic, which are able to promote health and prevent infections against enteropathogenic bacteria $[8,9]$. LAB are usually harbor carbohydrate-rich environments and found in various food products such as milk, plant, meat, intestinal mucosa of human, and animals $[8,10]$ but especially proliferate in different fermented foods [11]. Owing to particular physiological and biochemical traits, such as exopolysaccharide production, organic acids, aromatic compounds, tolerance to low water activity, and antimicrobial production $[5,12$, 13], LAB found different industrial applications, either by 
their biopreservatives or techno-functional properties [14]. In fact, many authors reported that some LAB strains are able to inhibit food-borne pathogens such as Staphylococcus aureus, Salmonella typhimurium, Escherichia, coli and Listeria monocytogenes $[15,16]$. In addition, $\mathrm{LAB}$ are efficient to inhibit mycotoxicogenic fungi (Penicillium expansum, Botrytis cinerea, Aspergillus niger, Aspergillus flavus, and Fusarium graminarum) $[17,18]$ as well as phytopathogenic bacteria (such as Xanthomonas campestris and Erwinia carotovora) [17].

Data reporting $\mathrm{LAB}$ isolation from soils and plants remain scarce. However, environmental and wild LAB strains are theoretically good competitors for different growth factors and production of antagonistic compounds but often undervalued. Olive tree is one of the most important crops in Tunisia, from North to the South but also accompanied all the Mediterranean civilizations. It is recognized for its beneficial effects on human health, even by olive oil or by different derived products [19]. Moreover, truffles are ectomycorrhizal consumable tuber, which are typical of semiarid land and are known by their important economical income for local population and their good taste $[20,21]$. The specificity of rhizospheric samples for bacterial isolation is their direct contact with both plant and soil, but especially because the associated bacteria have coevolved with plant pathogenic bacteria and fungi. This study aimed to isolate LAB from olive tree and desert-truffle rhizospheric soils and to evaluate their biotechnological properties.

\section{Materials and Methods}

2.1. Samples and Microbial Strains Origin. LAB strains were obtained from rhizospheric samples (49) which were collected from 8 sites located in the following regions in Tunisia: Jendouba, Ben Arous, Tunis, Kairouan, Gafsa, kebeli, Gabes, and Mednine. Samples were collected in sterilized bags, kept in cool box $\left(<10^{\circ} \mathrm{C}\right)$ containing ice packs during the transport to laboratory, and processed within 7 days. Different other microbial species were used in antimicrobial testing. Pseudomonas savastanoi knW2, Pantoea agglomerans kn45, and Stenotrophomonas maltophilia KnT2 were previously isolated from olive knots [22]. Listeria monocytogenes L15 and Botrytis cinerea were obtained from the Laboratory of Microorganisms and Active Biomolecules (LMBA), Faculty of Sciences of Tunis. Penicillium expansum and Aspergillus niger from Laboratory of Microbial Ecology and Biotechnology, University of Paul Cézanne, France and Verticillium dahliae from the National Institute of Agronomic Research of Tunis (INRAT). Reference strains from the American Type Culture Collection (ATCC) were also used including Enterococcus faecium ATCC 19434, Enterococcus faecalis ATCC 29212, Staphylococcus aureus ATCC 25923, and S. aureus ATCC 6538.

2.2. Lactic Acid Bacteria Isolation Procedure. The LAB from rhizospheres were isolated by the accumulation method as described by Chen et al. [23], with some modifications. Samples of $1 \mathrm{~g}$ were aseptically transferred into tubes of $15 \mathrm{~mL}$ containing $5 \mathrm{~mL}$ of MRS broth (Biolife) and incubated in anaerobic candle jars at $30^{\circ} \mathrm{C}$ for 3 days. After incubation, samples were serially diluted in $0.75 \% \mathrm{NaCl}$ solution. Fractions of $0.1 \mathrm{~mL}$ of the dilutions ranging between $10^{-5}$ and $10^{-8}$ were plated in duplicate on the surface of MRS agar (Biolife) [24] supplemented with $0.0025 \%$ of bromocresol green (MP Biomedicals) and $0.01 \%$ cycloheximide (MP Biomedicals) to inhibit fungal growth. The plates were incubated in the same conditions. The different colonies of acid-producing bacteria, determined by a yellow zone in the media around each colony, were picked and purified on MRS agar. Grampositive and catalase-negative isolates were selected and maintained in broth with $25 \%$ glycerol at $-80^{\circ} \mathrm{C}$ for further identification. The isolates were also tested for gas production from D-glucose (Bio Basic) (using inverted Durham tubes in MRS broth), growth at different temperatures $\left(10\right.$ and $\left.45^{\circ} \mathrm{C}\right)$, different $\mathrm{pH}$ (4.0 and 9.6), and different concentration of $\mathrm{NaCl}(3,6.5,8$, and 9\%) in MRS broth.

\subsection{DNA Extraction and PCR Amplification of $16 S-23 S$ rDNA} Internal Transcribed Spacer and the $16 S$ rDNA Gene. DNA was extracted by using a $\mathrm{CTAB} / \mathrm{NaCl}$ method described by Wilson [25] and modified by using $1 \mathrm{mg} / \mathrm{mL}$ lysozyme (BIOMATIK) for cell wall digestion. DNA electrophoresis was performed on a $0.8 \%$ agarose gel and visualized under UV light according to the standard procedure of [26]. The PCR amplifications were performed using a thermal cycler (Thermal Cycler; Bio-Rad).

The bacterial collection was dereplicated by fingerprinting analysis of the rRNA 16S-23S intergenic transcribed spacer (ITS) region, using universal primers, s-d-bact-1494a-20 and s-d-bact-0035-a-15 [27]. The ITS-PCR amplification consisted of 1X PCR reaction buffer, $1.5 \mathrm{mM} \mathrm{MgCl}_{2}, 0.2 \mathrm{mM}$ of dNTPs mixture, $0.5 \mu \mathrm{M}$ of each primer, $1 \mathrm{U}$ Taq polymerase (Fermentas), and $150 \mathrm{ng}$ of total DNA, using the following program: $94^{\circ} \mathrm{C}$ for $3 \mathrm{~min}$, followed by 35 cycles of $94^{\circ} \mathrm{C}$ for $45^{\circ} \mathrm{C}, 55^{\circ} \mathrm{C}$ for $1 \mathrm{~min}$ and $72^{\circ} \mathrm{C}$ for $2 \mathrm{~min}$, and a final extension step at $72^{\circ} \mathrm{C}$ for $7 \mathrm{~min}$. Strains exhibiting the same band patterns were grouped in the same ITS-haplotype. One or two representative strains from each group have been selected for subsequent identification using 16S rRNA genes sequencing. The $16 \mathrm{~S}$ rRNA amplification was performed using the describe primers s-d-bact-0008-a-S-20 and s-dbact-1495-a-A20 [27] and the thermal profile as mentioned previously. The ITS-PCR amplification and $16 \mathrm{~S}$ products were migrated, respectively, on 2 and $1.5 \%$ agarose gels in $0.5 \times$ Tris-borate-EDTA buffer (reagents from Fluka-Biochemika) and stained with ethidium bromide (Sigma-Aldrich).

2.4. $16 S$ rDNA Gene Sequencing and Phylogenetic Analysis. The 16S rDNA PCR amplicons were purified with Exonuclease-I and Shrimp Alkaline Phosphatase (ExoSap, Fermentas, Life Sciences) following the manufacturer's standard protocol. Sequence analyses of the purified DNAs were performed using a Big Dye Terminator cycle sequencing kit V3.1 (Applied Biosystems) and an Applied Biosystems 3130XL Capillary DNA Sequencer machine. Sequence similarities were found by BLAST analysis [28] using the 
GenBank DNA databases (http://www.ncbi.nih.gov) and the Ribosomal Database Project (RDP). Phylogenetic analysis of the 16S rRNA gene sequences were conducted with Molecular Evolutionary Genetics Analysis (MEGA) software, version 5 [29]. Trees were constructed by using neighbor-joining method [30].

2.5. Nucleotide Sequence Accession Numbers. The sequences of the 16S rDNA gene of rhizospheric LAB isolates samples have been submitted to the GenBank databases under accession numbers KC568531 to KC568560.

2.6. Antibacterial Activity of LAB against Pathogen, FoodBorne, and Phytopathogenic Bacteria. The antibacterial activity test was performed using the agar-well-diffusion method described by Tagg and McGiven [31]. Five bacterial strains were used as indicators to evaluate the antibacterial activity of LAB, involving S. aureus ATCC6538, L. monocytogenes L15, St. maltophilia, Ps. savastanoi, and Pa. agglomerans. The cell-free supernatants (CFS) of LAB culture ( $48 \mathrm{~h}$ ) in MRS broth were tested. All indicator strains were grown in $\mathrm{BHI}$ broth at $37^{\circ} \mathrm{C}$. Trypticase soy agar plates were overlaid with $5 \mathrm{~mL}$ of soft agar $(0.75 \%)$ containing $50 \mu \mathrm{L}$ of freshly grown culture. The wells were made in agar and filled with $100 \mu \mathrm{L}$ of the tested strain CFS. After incubation at $37^{\circ} \mathrm{C}$ for $18 \mathrm{~h}$, the diameter of the inhibition zones was measured. The spectrum of inhibitory effect of LAB was than evaluated on indicator bacteria: E. faecium ATCC19434, E. faecalis ATCC 29212, S. aureus ATCC 6538, and S. aureus ATCC 25923. All antibacterial tests were performed in triplicate.

2.7. Antifungal Activity of $L A B$. The LAB isolates were tested against four phytopathogenic fungi of Aspergillus niger, Penicillium expansum, Botrytis cinerea, and Verticillium dahliae using the method described by Whipps [32] with some modifications. A dual culture of the tested pathogen fungi and the presumed antagonist LAB was established in MRS agar without sodium acetate (MRS-SA). A mycelium plug of $5 \mathrm{~mm}$ was taken from the peripheral edge of old cultures (5 days) on PDA plates of fungal pathogens and each plug was placed at the centre of three replicate MRS-SA plates. Bacteria were inoculated at $2 \mathrm{~cm}$ line from the edge of plates and allowed to grow at $30^{\circ} \mathrm{C}$ for $48 \mathrm{~h}$. Untreated control plates were plated with pathogen plugs only. Particularly for $V$. dahliae, the fungus was placed on MRS-SA five days in advance, due to its relatively slower mycelium growth. All plates were incubated on adequate growth temperature of the fungi, and the percentage of growth inhibition was calculated by using the formula of Whipps [32]: [(R1-R2)/R1]*100, where R1 is the radial distance $(\mathrm{mm})$ grown by phytopathogenic fungi in direction of the antagonist and R2 is the radial distance grown by phytopathogenic fungi.

2.8. Exopolysaccharide Production and Proteolytic Activity. The exopolysaccharide production (EPS) was evaluated by streaking fresh culture of LAB isolates on MRS agar supplemented with $2 \%(\mathrm{w} / \mathrm{v})$ of sucrose (Sigma, Life science). After incubation at $30^{\circ} \mathrm{C}$ under anaerobic condition for $72 \mathrm{~h}$, development of a mucoid colony on agar medium or long filaments (when the colony is extended with an inoculation loop) indicated the production of exopolysaccharides [33]. As well, LAB were assessed for proteolytic activity by agarwell-diffusion test in MRS containing 4\% of skimmed milk (Scharlau). The diameter of the proteolysis zone was determined after incubation under anaerobic conditions at $30^{\circ} \mathrm{C}$ for $72 \mathrm{~h}$ and examined for clear zone around the wells.

2.9. Antibiotic Susceptibility. The antibiotic susceptibility was tested by disk diffusion method on BHIA as recommended by the standard criteria (CLSI, 2010). The antibiotics used (BioRad Laboratoires, Hercules, CA, USA) for susceptibility of enterococci were ampicillin (AM; $10 \mu \mathrm{g}$ ), ciprofloxacin (CIP; $5 \mu \mathrm{g}$ ), chloroamphenicol (C; $30 \mu \mathrm{g})$, erythromycin (E; $15 \mu \mathrm{g}$ ), gentamycin (GM; $120 \mu \mathrm{g}$ ), streptomycin (S; $300 \mu \mathrm{g})$, tetracycline (TE; $30 \mu \mathrm{g}$ ), teicoplanin (TEI; $30 \mu \mathrm{g}$ ), and vancomycin (VAN; $30 \mu \mathrm{g}$ ). Antibiotic discs were placed on solid media and incubated at $37^{\circ} \mathrm{C}$ for $24 \mathrm{~h}$. Based on the inhibition zone size, the results were interpreted as resistant (R), intermediate resistant (IR), or susceptible to the antimicrobial agents (S).

\section{Results and Discussion}

3.1. Lactic Acid Bacteria Isolation. LAB isolates were initially selected based on their ability to produce lactic acid by the presence of yellow halo surrounding the colonies on MRS-bromocresol green plates. Only Gram-positive strains exhibiting the absence of catalase and oxidase activity were kept on MRS agar for further identification. In total, 119 LAB strains were isolated from rhizospheric samples of desert truffles (4) and olive trees (49) from diverse geographic regions in Tunisia (Table 1). LAB are usually isolated from fermented products of animal and vegetable origin. However, low rate of "somnicells" of LAB [34] are naturally found in different environments which are close to these biota, such as floor of henhouse, rhizosphere of fruit trees, and around horse barn $[23,35]$. Although LAB isolation from soil and water remains scarce $[23,36]$, their presence in rhizospheric samples seems to be more supported by the abundance of root exudates [37].

3.2. Ribotyping and Identification of Isolates by $16 S$ rRNA Gene Sequence Analysis. Length polymorphism analysis of amplified 16S-23S internal transcribed spacer (ITS) was used to select representative strains of the different taxonomic units issued from the LAB collection. In fact, different studies have previously reported the usefulness of ITS dereplication for inter- and intradifferentiation at the genus/species level $[38,39]$ due to the high variability of these internal spacers. Based on this method, 16 different ITS-haplotypes designated from A to L were distinguished. ITS-PCR patterns showed 1 to 4 reproducible bands ranging from 275 to about $600 \mathrm{bp}$ (Figure 1). The representative isolates of each ITS-type (30 isolates) were identified at species level by $16 \mathrm{~S}$ rDNA gene sequence analysis and compared to the known sequences in GenBank. Phylogenetic relationship between LAB was constructed based on the 16S rDNA sequences from evolutionary distances by the neighbor-joining method (Figure 2). 


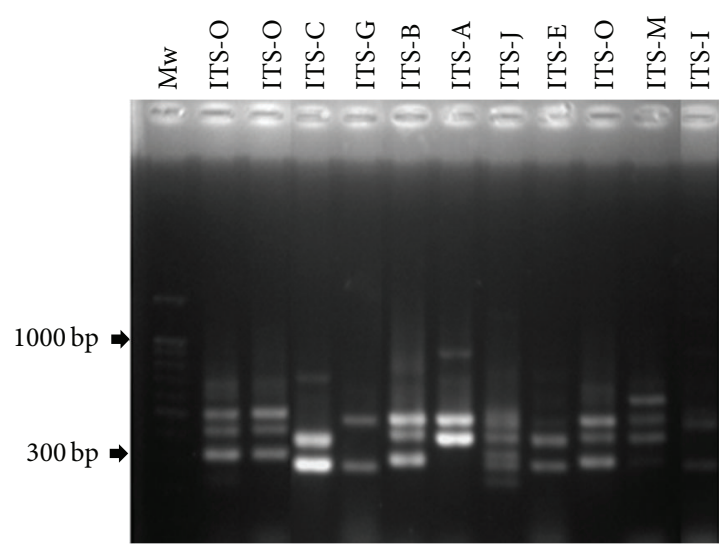

(a)

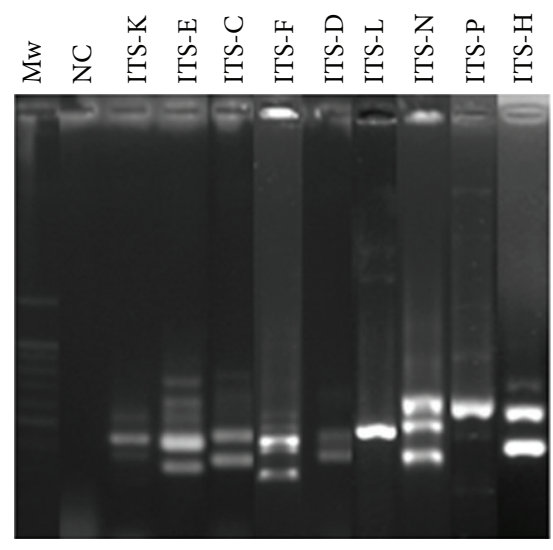

(b)

Figure 1: Different ITS-haplotypes (A-P) of representative rhizospheric lactic acid bacteria. Mw, Molecular weight (100 bp); NC, negative control.

Phylogenetic analysis revealed the differentiation of 5 clusters $(\mathrm{I}-\mathrm{V})$ and 11 subclusters that include members of the genera Enterococcus, Lactobacillus, Pediococcus, Lactococcus, Weissella, and Leuconostoc. The cluster I formed by the strains of Enterococcus genus was divided into 2 groups. The first group included three species of $E$. faecium, corresponding to the ITS-types (A, B, and C), E. durans (ITS-type D), and E. hirae (ITS-type E). The second group was only represented by the strain (FS11) of E. faecalis being the most closely related species in $100 \%$ of bootstrap analyses. The cluster II grouped strains of the genera Lactobacillus and Pediococcus and presented four subclusters (3 to 6) of $L b$. sakei, $L b$. plantarum, Pc. acidilactici, and Pc. pentosaceus based on the ITS-types G, H, I, and J, respectively. The cluster III formed by the strains of the genus Lactococcus was divided into two subclusters (7 and 8) of L. lactis (ITS-type K) and L. garvieae (ITS-type L). Furthermore, strains of the genus Weissella were grouped in the cluster IV, including three subclusters ( 9 to 11) of $W$. halotolerans (ITS-types M), W. paramesenteroides (ITS-types N), and W. confusa (ITS-types O). The cluster $\mathrm{V}$ was represented by one strain of $\mathrm{Ln}$. mesenteroides (ITStype $\mathrm{P}$ ). The used typing method showed that almost all the identified species were represented by one ITS-type, except for E. faecium, which showed an intraspecies heterogeneity with three major ITS-types (A, B, and C). In fact, E. faecium genome is extremely diverse [40] showing a high plasticity, due to the abundance of mobile genetic elements [41]. This result is in accordance with data published by Naïmi et al. [42], Park et al. [43], and Brtkova et al. [44], which reports the ITS region variability for E. faecium species. Together with $W$. confusa, this species was found to be the most isolated bacterium from rhizospheric samples (Table 1). Although enterococci are normal inhabitants of the human and animal gastrointestinal tract $[44,45]$, they are widely distributed in nature due to their high adaptation to various environmental conditions such as food, plants, water, and soil [46]. Moreover, the isolation of bacteria belonging to the genus Weissella was already reported either from soil [19] or plants [17]. With regard to others studies on LAB recovery from soil $[19,35,47,48]$ a higher number of species diversity is recorded in olive tree and truffle rhizospheric samples such as $L b$. sakei, Pc. acidilactici, and W. halotolerans. These species are naturally found on several raw fermented food products of plant and animal origin [49-51]; moreover, $P$. acidilactici is emerging as a potential probiotic in animal and human [52].

3.3. Physiological and Technological Properties of LAB. The physiological and biochemical characteristics including salt tolerance, growth at different temperatures, and gas production from glucose of all the strains are presented in Table 2. The majority of isolated strains were coccoid and coccoidrods and only $5.9 \%$ showed rod shape. The majority of isolates were homofermentative, and only 13 (10.9\%) were heterofermentative. From the total isolates $(n=79) 66.4 \%$ and $(n=10) 8.4 \%$ of bacterial isolates grew well in low activity water, 8 and $9 \% \mathrm{NaCl}$, respectively. The LAB strains with high tolerance to $9 \% \mathrm{NaCl}$ belonged to $W$. halotolerans (FS58), W. confusa (FS66, FS44, FS53, FS54, and FS63), L. lactis (LFS20), Lb. sakei (FS62), and E. faecium (FS77 and FS103). All LAB isolates grew well in $\mathrm{pH} 4.0$ and $10^{\circ} \mathrm{C}$. A total of $28(23 \%)$ and $14(11.5 \%)$ of isolates were not able to grow in $\mathrm{pH} 9.6$ and $45^{\circ} \mathrm{C}$, respectively. Besides, LAB were screened for proteolytic activity and EPS production on MRS medium containing sucrose and skim milk, respectively. Results showed that all LAB isolates exhibited proteolytic activities in the cell-free supernatants as revealed by a clear halo surrounding the wells. However, the proteolytic activity varied among the strains according to the halo diameters. In fact, the more proteolytic strains (58.8\%) exhibited a diameter greater than $15 \mathrm{~mm}$. The most proteolytic activity $(19 \mathrm{~mm}$ of diameter) was recorded for the strain Pc. acidilactici FS46. The exopolysaccharide production was detected in $42.8 \%$ of the isolates (Table 2 ). The good EPS-LAB producers belonged mainly to the species $W$. confusa (12 strains), $W$. paramesenteroides (FS60 and FS45), and Ln. mesenteroides FS13. The recorded physiochemical properties of the isolated rhizospheric LAB, for instance proteolytic activity, tolerance 


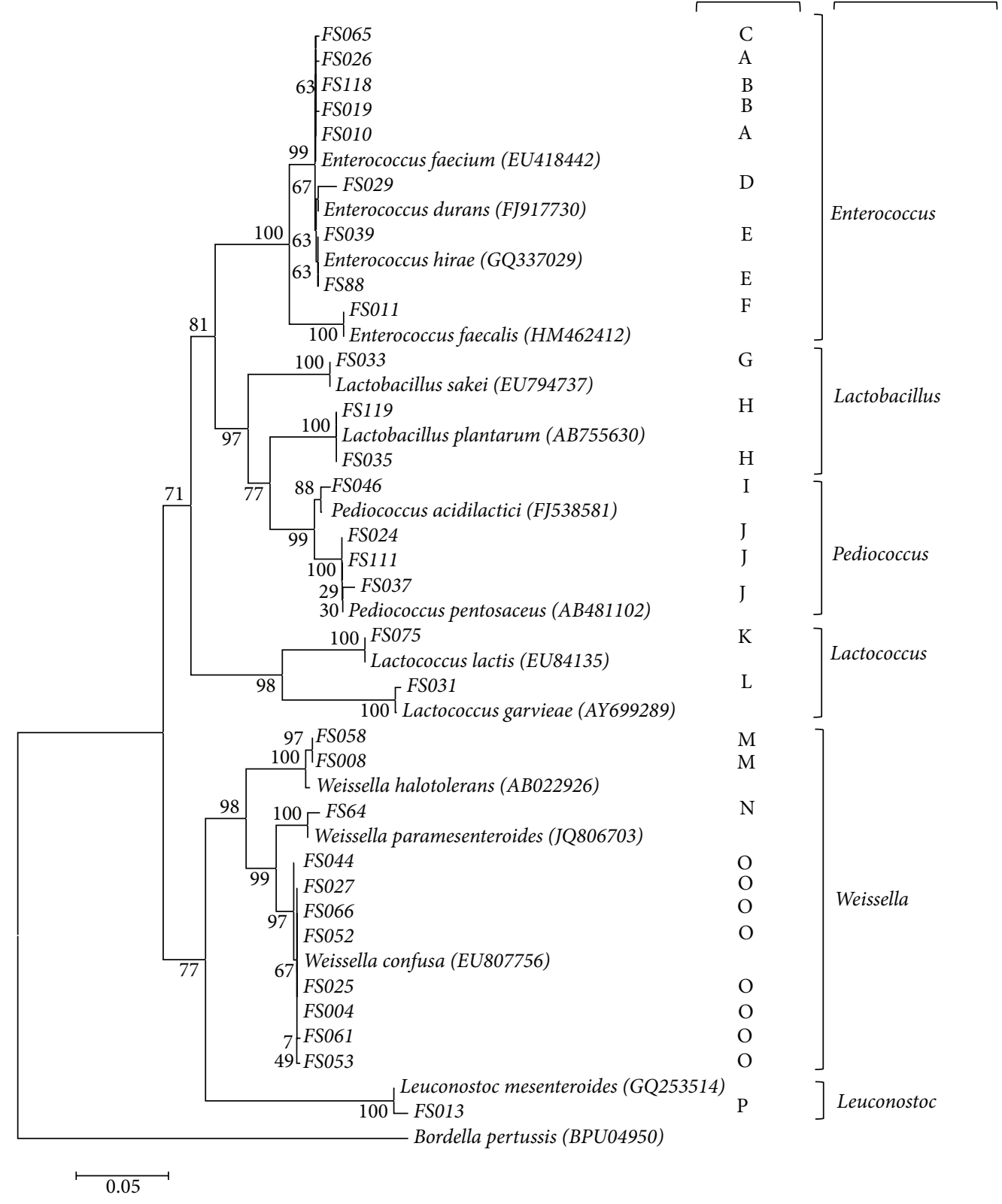

FIgURE 2: Phylogenetic tree showing the relative position of lactic acid bacteria isolates based on $16 \mathrm{~S}$ rDNA partial sequences, using the neighbor-joining method. Bordetella pertussis was used as an out group. Bootstrap values for a total of 1000 replicates are shown at the nodes of the tree, using MEGA-5. The scale bar corresponds to 0.05 units of the number of base substitutions per site.

to high $\mathrm{NaCl}$ concentration, and the EPS production could explain their survival in such oligotrophic environments. In particular, EPSs are typically correlated with bacterial resistance and protection against different stress conditions such as desiccation, salt stress, and UV radiations [53, 54]. But it also generally implicated in their adherence to biological surface and sodium toxicity reduction [55].

3.4. Antibiotic Susceptibility Testing. The antibiotic susceptibility of the isolated was mainly checked for enterococcal species, since they are the predominant isolates in the collection (Table 3 ) and could present a risk for antibiotic resistance gene dissemination. Rhizospheric enterococci showed low percentage of resistance to chloramphenicol (3.75\%), erythromycin (3.75\%), streptomycin (7.5\%), and tetracycline $(8.75 \%)$. Nevertheless, all the strains were susceptible to teicoplanin, ampicillin, and gentamicin. Furthermore, some strains (3.7\%) exhibited intermediate resistance to vancomycin and a high frequency of resistance to ciprofloxacin (36.2\%). In summary, the rhizospheric enterococci showed a low frequency of resistance to the Gram-positive target 


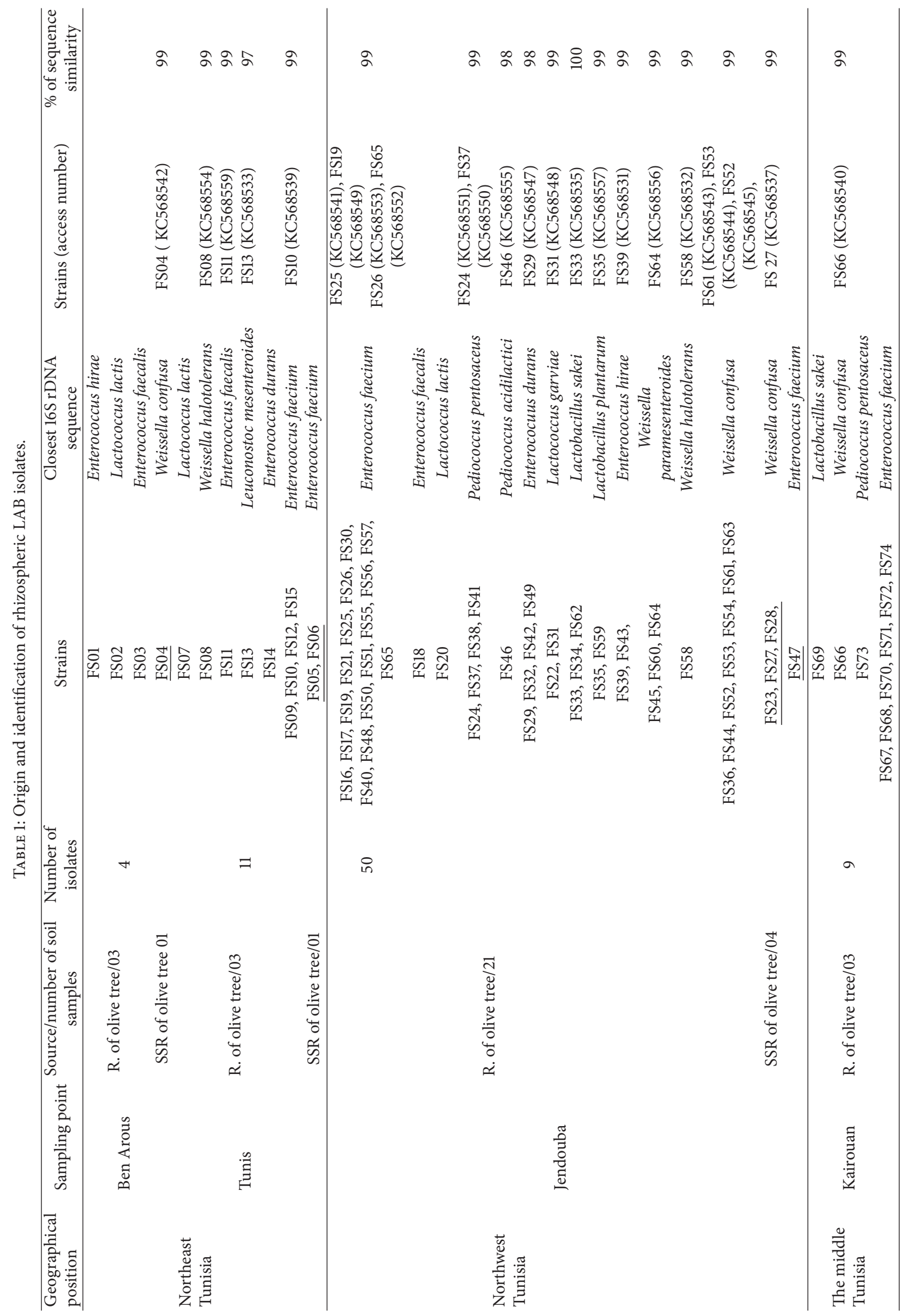




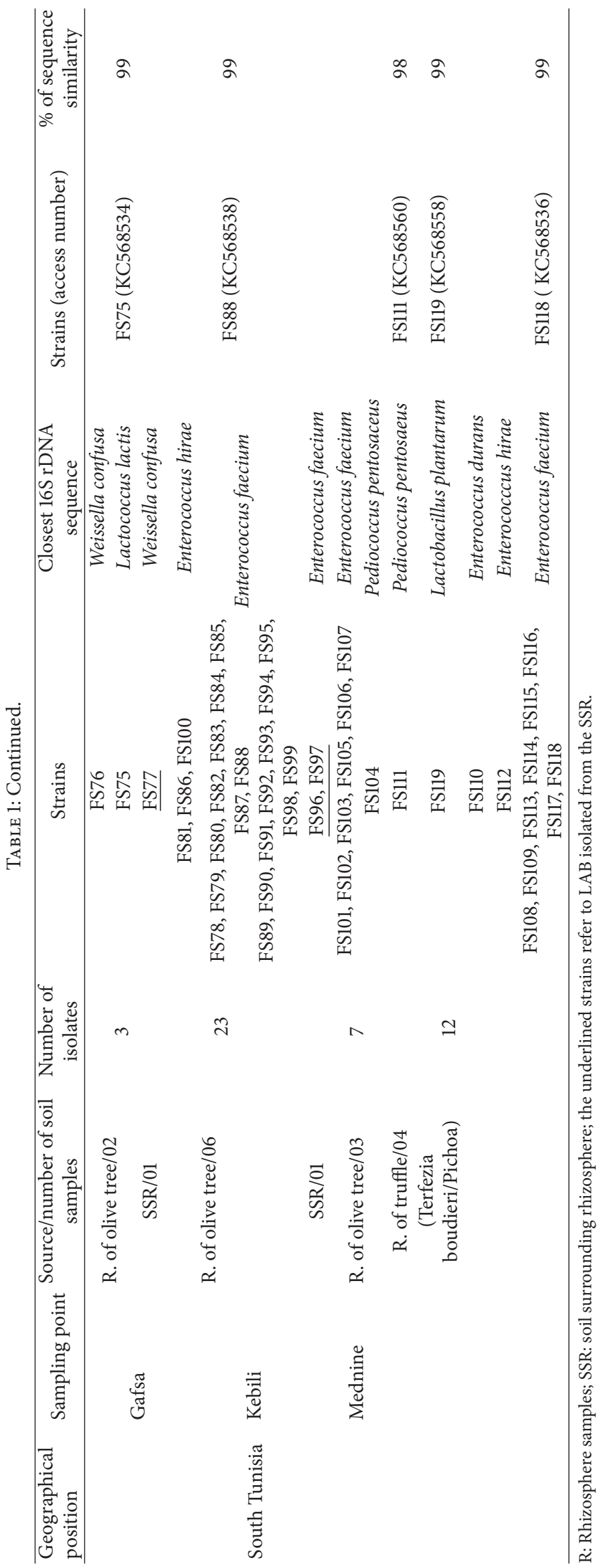




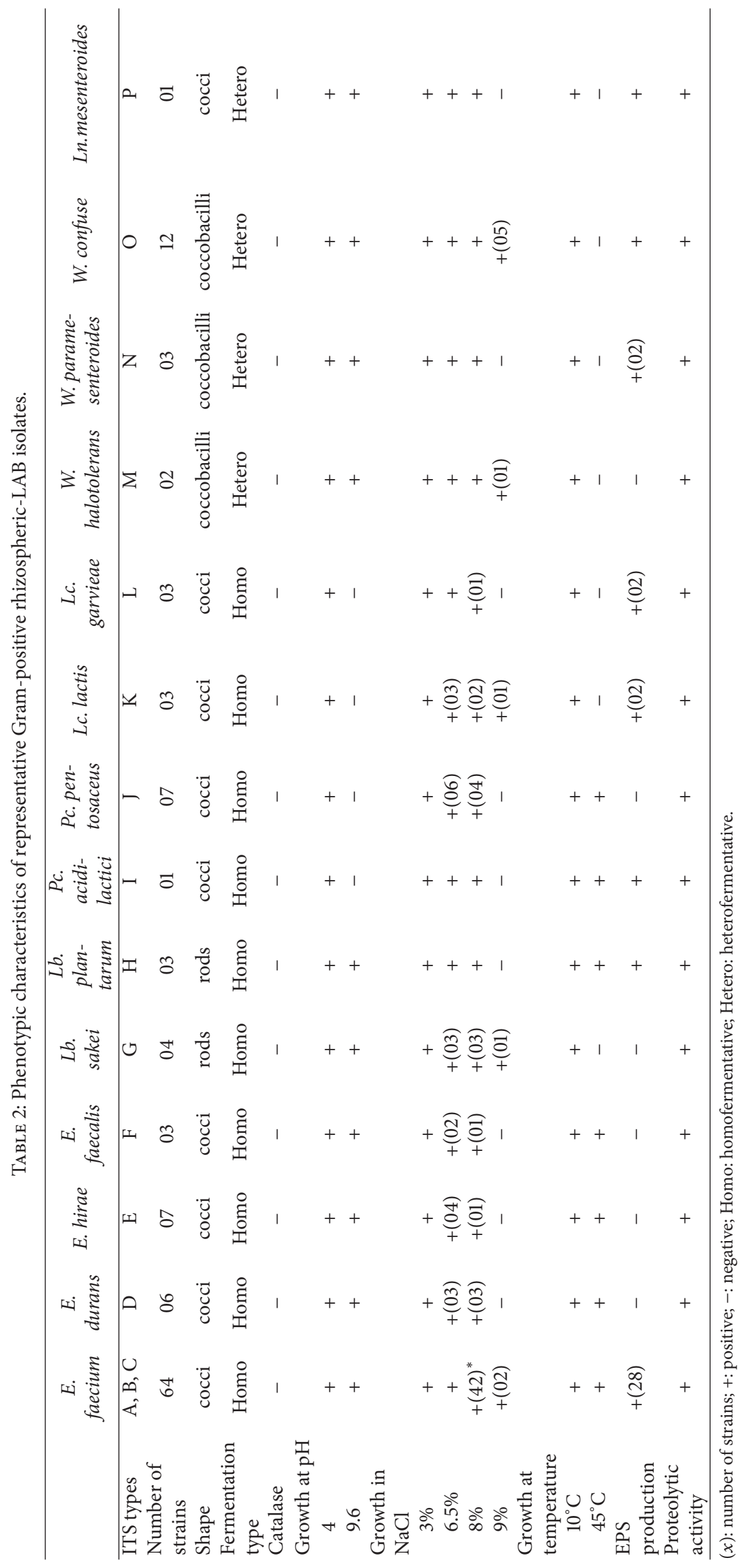


TABLE 3: Antimicrobial susceptibility of the enterococci isolated from the rhizosphere soils.

\begin{tabular}{|c|c|c|c|c|c|c|}
\hline Antibiotics & & $\begin{array}{c}\text { E. faecium } \\
(n=64)\end{array}$ & $\begin{array}{c}\text { E. faecalis } \\
(n=3)\end{array}$ & $\begin{array}{c}\text { E. durans } \\
(n=6)\end{array}$ & $\begin{array}{l}\text { E. hirae } \\
(n=7)\end{array}$ & $\%$ resistance \\
\hline Penicillins & $\mathrm{AM}$ & 0 & 0 & 0 & 0 & 0 \\
\hline \multirow[t]{3}{*}{ Aminoglycosides } & GM & 0 & 0 & 0 & 0 & 0 \\
\hline & $\mathrm{TE}$ & 6 & 0 & 1 & 0 & 8,75 \\
\hline & S & 6 & 0 & 0 & 0 & 7,5 \\
\hline Chloramphenicols & $\mathrm{CH}$ & 3 & 0 & 0 & 0 & 3,75 \\
\hline Macrolides & $\mathrm{E}$ & 2 & 1 & 0 & 0 & 3,75 \\
\hline \multirow[t]{2}{*}{ Glycopeptides } & VA & 3 & 0 & 0 & 0 & 3,75 \\
\hline & TEI & 0 & 0 & 0 & 0 & 0 \\
\hline Fluoroquinolones & CIP & 28 & 1 & 0 & 0 & 36,25 \\
\hline
\end{tabular}

AM: ampicillin, GM: gentamicine, TE: teteracyclin, S: streptomycin, E: erythromycin, C: chloramphenicol, VA: vancomycin, TEI: teicoplanin, and CIP: ciprofloxacin. $n$ : total number of strains; numbers indicated resistant strains within species.

TABLE 4: Antibacterial activity spectrum of neutralized cell-free supernatant of three LAB rhizospheric isolates.

\begin{tabular}{|c|c|c|c|c|c|c|}
\hline Strains & & $\begin{array}{c}\text { L. monocytogenes } \\
\text { L15 }\end{array}$ & $\begin{array}{c}\text { S. aureus ATCC } \\
6538\end{array}$ & $\begin{array}{c}\text { S. aureus ATCC } \\
25923\end{array}$ & $\begin{array}{c}\text { E. faecium } \\
\text { ATCC } 19129\end{array}$ & $\begin{array}{c}\text { E. faecalis ATCC } \\
29212\end{array}$ \\
\hline Leuconostoc mesenteroides & FS013 & $21 \pm 1.00$ & $14 \pm 1.00$ & $12 \pm 1.00$ & $13 \pm 1.00$ & $10 \pm 0.00$ \\
\hline Weissella halotolerans & FS008 & $17 \pm 1.00$ & $15 \pm 1.00$ & $20 \pm 1.00$ & $13.5 \pm 1.00$ & $11 \pm 1.00$ \\
\hline Enterococcus faecium & FS071 & $16 \pm 1.00$ & $15 \pm 1.05$ & $19 \pm 1.73$ & $14.5 \pm 0.80$ & $15.5 \pm 1.32$ \\
\hline
\end{tabular}

Numbers indicated the diameter of the inhibition zone in $\mathrm{mm}$; each value represents the mean value standard deviation (SD) from three trials; values in the same column differ significantly $(P<0.05)$.

antibiotics compared to food, clinical, and animal isolates $[56,57]$. This result indicates the safety of these bacteria for a potential technological application.

3.5. In Vitro Screening of the Antagonistic Activity of LAB against Human, Plant, and Food-Borne Pathogenic Bacteria. $\mathrm{LAB}$ isolates were screened for antibacterial activity against human and plant pathogens, including St. maltophilia, $\mathrm{Pa}$. agglomerans, and Ps. savastanoi and food-borne bacteria of $S$. aureus and L. monocytogenes (Figure 3(a)). According to their inhibitory effects on pathogens, LAB were differentiated into three classes: strong inhibitor (with growth inhibition diameter $(d) \geq 19 \mathrm{~mm})$, medium $(14 \leq d<19 \mathrm{~mm})$, and with no significant inhibitory effect for a diameter less than $14 \mathrm{~mm}$ (Figure 4(a)). The results showed that 64 strains $(53.8 \%)$ have significant inhibition against St. maltophilia, among them 12 strains $(10 \%)$ with strong inhibitory activity. This activity was recorded for the species of $L b$. plantarum, $L b$. sakei, Lc. garvieae, Ln. mesenteroides, and Pc. pentosaceus and mostly for the genera Enterococcus and Weissella. Five isolates (4\%) including three E. faecium (FS70, FS01, and FS03) and two Pc. pentosaceus (FS73 and FS24) showed strong inhibitory activity against $\mathrm{Pa}$. agglomerans. Eleven isolates belonging to species $W$. confusa, Lc. Lactis, $L b$. plantarum, Ln. mesenteroides, E. durans, and E. faecium showed also strong inhibitory activity against $P$ s. savastanoi (diameter varied between 19 to $28 \mathrm{~mm}$ ). The recorded high level of inhibition highlights the biotechnological potential of rhizospheric-LAB to control phytopathogens, particularly for $\mathrm{Pa}$. agglomerans and St. maltophilia, which are also increasingly identified as important cause of nosocomial human infections [58, 59] and among the emergent multidrug resistant Gram-negative bacteria [59]. With regard to the food-borne pathogen, efficient inhibition was recorded for $W$. confusa FS054 strain (28 mm) against S. aureus, for E. faecium FS106 against $L$. monocytogenes $(20 \mathrm{~mm})$ and for the strain $W$. confusa FS036 against both S. aureus $(20 \mathrm{~mm})$, and L. monocytogenes $(24 \mathrm{~mm})$. It is of interest to note that the genera of Enterococcus and Weissella may become potential biopreservation agents of food-poisoning and plant-borne species.

This antibacterial activity exhibited by the majority of strains especially toward Gram-negative bacteria may be due to the organic acid effect or to other compounds active in acidic conditions. For this purpose, the inhibitory effect was checked after supernatant neutralization. By this way, only three strains of E. faecium FS071, Ln. mesenteroides FS013, and $W$. halotolerans FS008 retained the inhibition ability against the tested pathogens (Table 4), leading to suggest the presence of bacteriocin-like substances. This result was also supported by the broad spectrum known for the majority of the identified enterocins $[60,61]$. Further studies should be conducted to elucidate the nature of the antibacterial metabolites produced by selected LAB, especially by $W$. halotolerans FS008 strain. Moreover, different studies proposed that enterococci may have a prospectively useful role in some dairy products, due to their proteolytic and lipolytic activities, and may then contribute to the development of the organoleptic properties of fermented foods, and also due to the production of enterocins with anti-Listeria activity $[62,63]$.

3.6. Antifungal Activity of $L A B$. LAB isolates were screened for antifungal activity against soil-borne fungi of $B$. cinerea 

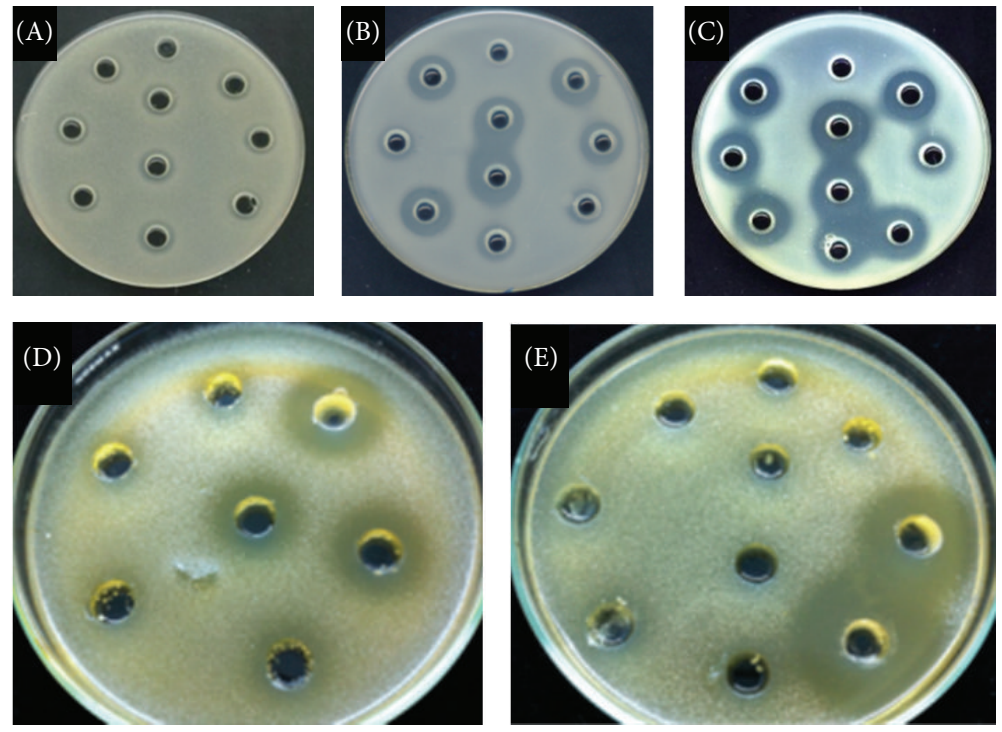

(a)
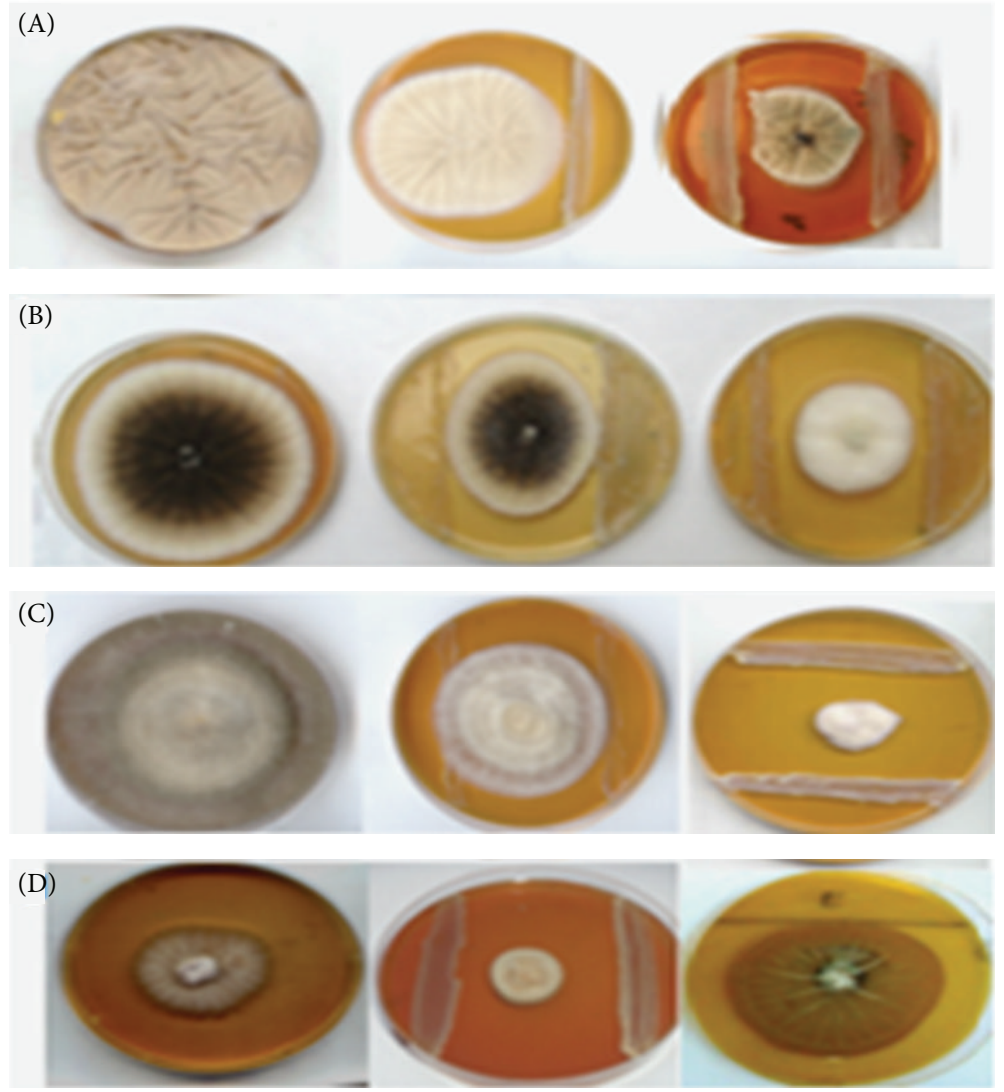

(b)

FIgURE 3: Antimicrobial activity of some rhizospheric LAB against pathogenic bacteria (a) Pa. agglomerans (A), St. maltophilia (B), Ps. savastanoi (C), L. monocytogenes (D), and S. aureus (E) by-agar well-diffusion method [31] and phytopathogen fungi (b) P. expansium (A), A. niger (B), B. cinerea (C), and V. dahliae (D) by dual culture [32]. 


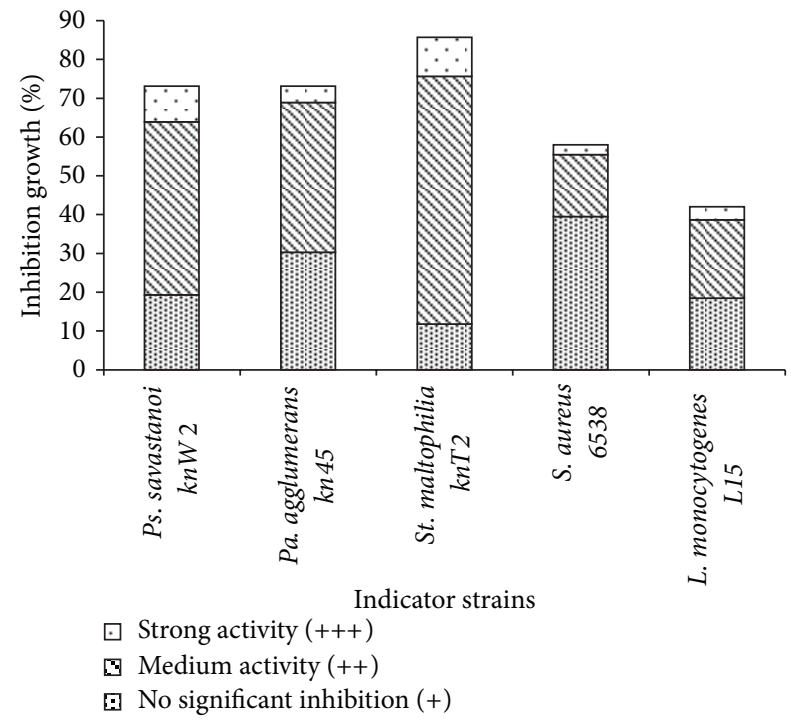

(a)

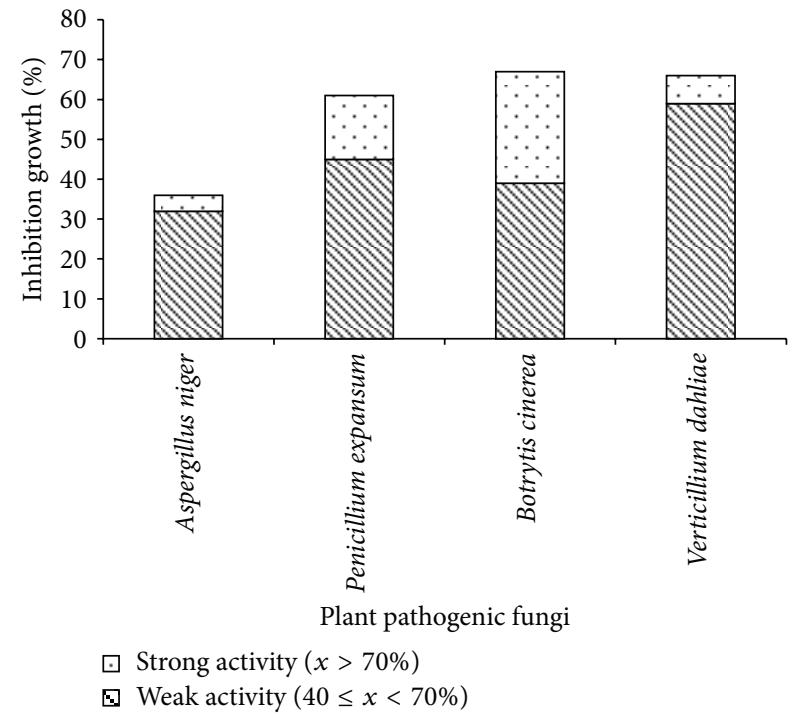

(b)

FIGURE 4: Histograms showing percentage of LAB having in vitro inhibitory effect on pathogenic and spoilage bacterial species (a) and plant pathogenic fungi (b). The experiments were repeated at least three times.

and $V$. dahliae and postharvest contaminants of A. niger and $P$. expansum on MRS-SA agar medium (Figure 3(b)). According to their degree of mycelium growth reduction, active $\mathrm{LAB}$ were classified into two main groups: low (reduction of mycelium growth between 40 and $70 \%$ ) and high antifungal activity (>70\% of inhibition) (Figure 4(b)). The results showed that the maximum growth inhibition rate $(28 \%$ of the strains) was registered for Botrytis cinerea (Figure 4(b)). The group of LAB strains with strong inhibition activity ( 75.3 to $92.6 \%$ inhibition) belonged to the species of W. paramesenteroides, W. confusa, E. durans, E. faecium and E. hirae. Besides, the most inhibitor strains toward the fungus $A$. niger were $E$. durans FS29 and four E. faecium, (FS50, FS06, FS48, and FS87) exhibiting an inhibition rate between 76.7 and $90 \%$. Furthermore, we noted that $16 \%$ of the strains belonging to the species E. faecium, E. durans, $W$. halotolerans, and $L b$. plantarum showed a strong inhibition rate ( 75.3 to $87.8 \%)$ toward $P$. expansum.

It is worth mentioning that strains of Enterococcus genus confirmed their antimicrobial efficacy by strong inhibition of most of the tested postharvest fungi ( $P$. expansum, $B$. cinerea, and $A$. niger) and highlight the potential use of rhizospheric-LAB as biocontrol agents to prevent postharvest deterioration caused by these fungi. In fact, most of these fungi produce allergenic spores and mycotoxins which are responsible of the spoilage and poisoning of foods leading to serious potential health hazards [64]. It is also the case of Lb. plantarum FS119 which was isolated from desert truffle rhizosphere, and that could be considered as a potential candidate inhibitor of $P$. expansum, the agent of blue mold in apples. In addition strains of the genus Weissella have showed an efficient inhibition toward either pathogenic bacteria, or the different tested fungi. This result is in accordance with Valerio et al. [65] and Lee et al. [66] reporting the emergence/selection of these bacteria as biocontrol agent and potential probiotic. Regarding the vascular wilt fungi $V$. dahlia, Enterococcal strains were also shown to be the most efficient inhibitor strains. The highest activity was observed for E. faecium FS82 with $75 \%$ of mycelium reduction (Table 5). This result constitute a first report on the strong inhibition of this soil-born-fungus, which is responsible of Verticillium wilt, a serious worldwide disease that affects many crops including fruits, vegetables, and oilseed rape and leads to dramatically yield losses [67]. Biological compounds investigation to control this pathogen is of great significance [68], as it persists in the soil and resists different chemical treatments. The present study showed that selected environmental $\mathrm{LAB}$ could offer an excellent source for active metabolite to control different pathogenic bacteria and fungi. As it was reported by many authors [5, 13, 69], different substances, such as organic acids, hydrogen peroxide, cyclic dipeptides, and phenolic and proteinaceus compounds could be responsible for the detected antifungal activity. Indeed, identification of the issued rhizospheric-LAB metabolites is needed for a more target application.

\section{Conclusion}

In this study, we reported for the first time the isolation and characterization of LAB from rhizosphere samples of olive trees and desert truffles. The results showed a high rate of antimicrobial activity among the isolates, indicating that rhizosphere may be a common source for the selection of LAB with important technological potential, which are useful for the biocontrol of food-, plant-, and soil-borne pathogenic bacteria and fungi. Further investigations to elucidate the nature of inhibiting compounds should be considered. 
TABLE 5: Mycelium growth inhibition of four pathogenic fungi by selected potent antifungal rizospheric-LAB isolates using confrontation assay.

\begin{tabular}{|c|c|c|c|c|c|}
\hline Strains & Species & A. niger & P. expansum & B. cinerea & V. dahlia \\
\hline FS29 & E. durans & $++(76.7)^{*}$ & $++80.2^{*}$ & $++(85.1)^{*}$ & $++(70.3)^{*}$ \\
\hline FS50 & E. faecium & $++(79.1)^{*}$ & + & $++(82.7)^{*}$ & + \\
\hline FS06 & E. faecium & $++(79)^{*}$ & $++(75.3)^{*}$ & + & + \\
\hline FS87 & E. faecium & $++(79.1)^{*}$ & + & $++(80.2)^{*}$ & + \\
\hline FS48 & E. faecium & $++(90)^{*}$ & $++(72.8)^{*}$ & $+++(82.7)^{*}$ & + \\
\hline FS82 & E. faecium & + & + & $+++(85.2)^{*}$ & $+++(75)^{*}$ \\
\hline FS68 & E. faecium & + & + & $++(75.3)^{*}$ & + \\
\hline FS05 & E. faecium & + & $++(80.2)^{*}$ & $++(72.8)^{*}$ & + \\
\hline FS14 & E. durans & + & $++(77.7)^{*}$ & $++(82.7)^{*}$ & - \\
\hline FS21 & E. faecium & + & $++(77.7)^{*}$ & + & $++(70.9)^{*}$ \\
\hline FS101 & E. faecium & + & $++(75.3)^{*}$ & $++(79)^{*}$ & + \\
\hline FS32 & E. durans & + & $++(72.8)^{*}$ & $++(82.7)^{*}$ & + \\
\hline FS107 & E. faecium & + & - & $++(80.2)^{*}$ & + \\
\hline FS45 & W. paramesenteroides & - & + & $++(81.4)^{*}$ & + \\
\hline FS61 & W. confusa. & - & + & $++(85)^{*}$ & - \\
\hline FS19 & E. faecium & + & + & $++(77.7)^{*}$ & + \\
\hline FS94 & E. faecium & + & $++(87.6)^{*}$ & $++(82.7)^{*}$ & + \\
\hline FS119 & Lb. plantarum & - & $++(83.8)^{*}$ & $++(70)^{*}$ & + \\
\hline FS49 & E. durans & - & $++(75.3)^{*}$ & + & + \\
\hline FS58 & W. halotolerans & + & $++(80.2)^{*}$ & + & - \\
\hline FS74 & E. faecium & - & $++(72.8)^{*}$ & $++(85.2)^{*}$ & $++(74.5)^{*}$ \\
\hline FS51 & E. faecium & + & $++(72.8)^{*}$ & $++(82.7)^{*}$ & $++(70.9)^{*}$ \\
\hline FS102 & E. faecium & - & + & $++(81.2)^{*}$ & + \\
\hline FS16 & E. faecium & - & - & $++(92.6)^{*}$ & - \\
\hline FS99 & E. faecium & - & + & $++(91.3)^{*}$ & + \\
\hline FS42 & E. durans & + & + & $++(85.1)^{*}$ & + \\
\hline FS12 & E. faecium & + & + & $++(75.3)^{*}$ & + \\
\hline FS65 & E. faecium & + & + & $++(77.7)^{*}$ & + \\
\hline FS15 & E. faecium & + & + & + & $++(70.3)^{*}$ \\
\hline FS106 & E. faecium & + & $++(70.3)^{*}$ & + & + \\
\hline FS53 & W. confusa & - & $++(71)^{*}$ & + & + \\
\hline FS77 & E. faecium & - & $++(78.4)^{*}$ & + & + \\
\hline
\end{tabular}

A. niger: Aspergillus niger, P. expansum: Penicillium expansum, B. cinerea: Botrytis cinerea, $V$. dahlia: Vercticillium dahliae. $(+)$ : weak antifungal activity having an inhibition rate between 40 and $70 \%$; (++): strong activity with an inhibition rate $\geq 70 \%$; the strains characterized with a broad range against different fungi appear in bold. Data were obtained at least three replicates. ${ }^{*}$ Means within column show statistically significant difference $(P<0.05)$ with a control (nonexposed to the bacteria).

\section{Acknowledgments}

The authors thank financial support of the European Union in the ambit of Project 20 BIODESERT (EU FP7-CSASA REGPOT-2008-2, Grant agreement no. 245746) and the 21 Tunisian Ministry of Higher Education and Scientific research in the ambit of the laboratory 22 projects LR MBA206 and LR11ES31.

\section{References}

[1] G. J. Guynes and E. O. Bennett, "Bacterial deterioration of emulsion oils. I. Relationship between aerobes and sulfatereducing bacteria in deterioration," Applied Microbiology, vol. 7, no. 2, pp. 117-121, 1959.
[2] J. I. Pitt and A. D. Hocking, Fungi and Food Spoilage, A Chapman and Hall Food Science Book, Aspen, Gaithersburg, Md, USA, 2nd edition, 1999.

[3] J. K. Huang, F. B. Qiao, L. X. Zhang, and S. Rozelle, "Farm pesticide, rice production, and human health," EEPSEA Working Paper, EEPSEA, Singapore, 2000.

[4] J. Huang, R. Hu, C. Pray, F. Qiao, and S. Rozelle, "Biotechnology as an alternative to chemical pesticides: a case study of Bt cotton in China," Agricultural Economics, vol. 29, no. 1, pp. 55-67, 2003.

[5] M. E. Stiles, "Biopreservation by lactic acid bacteria," Antonie van Leeuwenhoek, vol. 70, no. 4, pp. 331-345, 1996.

[6] N. Pastor, E. Carlier, J. Andrés, S. B. Rosas, and M. Rovera, "Characterization of rhizosphere bacteria for control of phytopathogenic fungi of tomato," Journal of Environmental Management, vol. 95, pp. S332-S337, 2012. 
[7] W. N. Konings, J. Kok, O. P. Kuipers, and B. Poolman, "Lactic acid bacteria: the bugs of the new millennium," Current Opinion in Microbiology, vol. 3, no. 3, pp. 276-282, 2000.

[8] M. F. Fernández, S. Boris, and C. Barbés, "Probiotic properties of human lactobacilli strains to be used in the gastrointestinal tract," Journal of Applied Microbiology, vol. 94, no. 3, pp. 449455, 2003.

[9] J. Skjermo and O. Vadstein, “Techniques for microbial control in the intensive rearing of marine larvae," Aquaculture, vol. 177, no. 1-4, pp. 333-343, 1999.

[10] M. Amin, M. Jorfi, A. D. Khosravi, A. R. Samarbafzadeh, and A. F. Sheikh, "Isolation and identification of Lactobacillus casei and Lactobacillus plantarum from plants by PCR and detection of their antibacterial activity," Journal of Biological Sciences, vol. 9, no. 8, pp. 810-814, 2009.

[11] A. H. Soomro, T. Masud, and K. Anwaar, "Role of lactic acid bacteria in food preservation and human health-a review," Pakistan Journal of Nutrition, vol. 1, no. 1, pp. 20-24, 2002.

[12] G. Giraffa, "Microbial polysaccharides produced by lactic acid bacteria in the dairy industry," Industrie Alimentari, vol. 33, no. 324, pp. 295-298, 1994.

[13] M. Mataragas, E. H. Drosinos, and J. Metaxopoulos, "Antagonistic activity of lactic acid bacteria against listeria monocytogenes in sliced cooked cured pork shoulder stored under vacuum or modified atmosphere at $4 \pm 2^{\circ} \mathrm{C}$," Food Microbiology, vol. 20, no. 2, pp. 259-265, 2003.

[14] R. Bizzarro, G. T. Tarelli, G. Giraffa, and E. Neviani, "Phenotypic and genotypic characterization of lactic acid bacteria isolated from Pecorino Toscano cheese," International Journal of Food Science, vol. 12, no. 3, pp. 303-316, 2000.

[15] R. K. Darsanaki, M. L. Rokhi, M. A. Aliabadi, and K. Issazadeh, "Antimicrobial activities of Lactobacillus strains isolated from fresh vegetables," Middle-East Journal of Scientific Research, vol. 11, no. 9, pp. 1216-1219, 2012.

[16] M. Jamuna and K. Jeevaratnam, "Isolation and partial characterization of bacteriocins from Pediococcus species," Applied Microbiology and Biotechnology, vol. 65, no. 4, pp. 433-439, 2004.

[17] R. Trias, L. Bañeras, E. Montesinos, and E. Badosa, "Lactic acid bacteria from fresh fruit and vegetables as biocontrol agents of phytopathogenic bacteria and fungi," International Microbiology, vol. 11, no. 4, pp. 231-236, 2008.

[18] P. Lavermicocca, F. Valerio, A. Evidente, S. Lazzaroni, A. Corsetti, and M. Gobbetti, "Purification and characterization of novel antifungal compounds from the sourdough Lactobacillus plantarum strain 21B," Applied and Environmental Microbiology, vol. 66, no. 9, pp. 4084-4090, 2000.

[19] L. Laitman, "Le marché et la production de l'huile d'olive en Tunisie," Annales de Géographie, vol. 62, no. 332, pp. 271-286, 1953.

[20] A. Morte, M. Zamora, A. Gutiérrez, and M. Honrubia, "Desert truffle cultivation in semiarid Mediterranean areas," in Mycorrhizas Functional Processes and Ecological Impact, C. AzcónAguilar et al., Ed., chapter 15, pp. 221-233, Springer, Berlin, 2009.

[21] A. Slama, Z. Fortas, M. Neffati, L. Khabar, and A. Boudabous, "Etude taxinomique de quelques Ascomycota hypogés (Terfeziaceae) de la Tunisie méridionale," Bulletin de la Société Mycologique de France, vol. 122, no. 2-3, pp. 187-195, 2006.

[22] H. Ouzari, A. Khsairi, N. Raddadi et al., "Diversity of auxinproducing bacteria associated to Pseudomonas savastanoiinduced olive knots," Journal of Basic Microbiology, vol. 48, no. 5, pp. 370-377, 2008.
[23] Y.-S. Chen, F. Yanagida, and I. Shinohara, "Isolation and identification of lactic acid bacteria from soil using an enrichment procedure," Letters in Applied Microbiology, vol. 40, no. 3, pp. 195-200, 2005.

[24] J. C. de Man, M. Rogosa, and M. E. Sharpe, "A medium for the cultivation of lactobacilli," Journal of Applied Microbiology, vol. 23, no. 1, pp. 130-135, 1960.

[25] K. Wilson, "Preparation of genomic DNA from bacteria," in Current Protocols in Molecular Biology, F. M. Ausubel, R. Brent, R. E. Kingston et al., Eds., pp. 2. 4. 1-2. 4. 5, 1987.

[26] J. Sambrook, E. F. Fritsch, and T. Maniatis, Molecular Cloning: A Laboratory Manual, Cold Spring Harbor Laboratory, Cold Spring Harbor, NY, USA, 2nd edition, 1989.

[27] D. Daffonchio, S. Borin, G. Frova, P. L. Manachini, and C. Sorlini, "PCR fingerprinting of whole genomes: the spacers between the 16s and 23S rRNA genes and of intergenic tRNA gene regions reveal a different intraspecific genomic variability of Bacillus cereus and Bacillus licheniformis," International Journal of Systematic Bacteriology, vol. 48, no. 1, pp. 107-116, 1998.

[28] S. F. Altschul, W. Gish, W. Miller, E. W. Myers, and D. J. Lipman, "Basic local alignment search tool," Journal of Molecular Biology, vol. 215, no. 3, pp. 403-410, 1990.

[29] K. Tamura, D. Peterson, N. Peterson, G. Stecher, M. Nei, and S. Kumar, "MEGA5: molecular evolutionary genetics analysis using maximum likelihood, evolutionary distance, and maximum parsimony methods," Molecular Biology and Evolution, vol. 28, no. 10, pp. 2731-2739, 2011.

[30] N. Saitou and M. Nei, "The neighbor-joining method: a new method for reconstructing phylogenetic trees," Molecular Biology and Evolution, vol. 4, no. 4, pp. 406-425, 1987.

[31] J. R. Tagg and A. R. McGiven, "Assay system for bacteriocins," Applied Microbiology, vol. 21, no. 5, p. 943, 1971.

[32] J. M. Whipps, "Effect of media on growth and interactions between a range of soil-borne glasshouse pathogens and antagonistic fungi," New Phytology, vol. 107, no. 1, pp. 127-142, 1987.

[33] P. Ruas-Madiedo and C. G. de los Reyes-Gavilán, "Invited review: methods for the screening, isolation, and characterization of exopolysaccharides produced by lactic acid bacteria," Journal of Dairy Science, vol. 88, no. 3, pp. 843-856, 2005.

[34] U. Behrendt, T. Müller, and W. Seyfarth, "The influence of extensification in grassland management on the populations of micro-organisms in the phyllosphere of grasses," Microbiological Research, vol. 152, no. 1, pp. 75-85, 1997.

[35] F. Yanagida, Y. Chen, and T. Shinohara, "Isolation and characterization of lactic acid bacteria from soils in vineyards," The Journal of General and Applied Microbiology, vol. 51, no. 5, pp. 313-318, 2005.

[36] F. Yanagida, Y. Chen, and M. Yasaki, "Isolation and characterization of lactic acid bacteria from lakes," Journal of Basic Microbiology, vol. 47, no. 2, pp. 184-190, 2007.

[37] P. D. Kiely, J. M. Haynes, C. H. Higgins et al., "Exploiting new systems-based strategies to elucidate plant-bacterial interactions in the rhizosphere," Microbial Ecology, vol. 51, no. 3, pp. 257-266, 2006.

[38] V. Gürtler and V. A. Stanisich, "New approaches to typing and identification of bacteria using the 16S-23S rDNA spacer region," Microbiology, vol. 142, no. 1, pp. 3-16, 1996.

[39] D. Daffonchio, A. Cherif, and S. Borin, "Homoduplex and heteroduplex polymorphisms of the amplified ribosomal 16S$23 \mathrm{~S}$ internal transcribed spacers describe genetic relationships in the 'Bacillus cereus group,' Applied and Environmental Microbiology, vol. 66, no. 12, pp. 5460-5468, 2000. 
[40] H. L. Leavis, R. J. L. Willems, W. J. B. van Wamel, F. H. Schuren, M. P. M. Caspers, and M. J. M. Bonten, "Insertion sequencedriven diversification creates a globally dispersed emerging multiresistant subspecies of E. faecium," PLoS Pathogens, vol. 3, no. 10, p. $37,2007$.

[41] W. van Schaik, J. Top, D. R. Riley et al., "Pyrosequencingbased comparative genome analysis of the nosocomial pathogen Enterococcus faecium and identification of a large transferable pathogenicity island," BMC Genomics, vol. 11, no. 1, article R239, 18 pages, 2010.

[42] A. Naïmi, G. Beck, and C. Branlant, "Primary and secondary structures of rRNA spacer regions in enterococci," Microbiology, vol. 143, no. 3, pp. 823-834, 1997.

[43] Y. Park, E. Oh, B. K. Kim, S. M. Kim, and S. I. Shim, "Phenotypic characteristics of Enterococcus faecium variants confirmed by intergenic ribosomal polymerase chain reaction and E. faecium polymerase chain reaction," Diagnostic Microbiology and Infectious Disease, vol. 34, no. 4, pp. 269-273, 1999.

[44] A. Brtkova, M. Filipova, H. Drahovska, and H. Bujdakova, "Characterization of enterococci of animal and environmental origin using phenotypic methods and comparison with PCR based methods," Veterinarni Medicina, vol. 55, no. 3, pp. 97-105, 2010.

[45] G. Giraffa, "Enterococci from foods," FEMS Microbiology Reviews, vol. 26, no. 2, pp. 163-171, 2002.

[46] J. O. Mundt, "Occurrence of enterococci on plants in a wild environment," Applied Microbiology, vol. 11, pp. 141-144, 1963.

[47] M. Zamudio-Maya, J. Narváez-Zapata, and R. Rojas-Herrera, "Isolation and identification of lactic acid bacteria from sediments of a coastal marsh using a differential selective medium," Letters in Applied Microbiology, vol. 46, no. 3, pp. 402-407, 2008.

[48] M. P. Lutz, V. Michel, C. Martinez, and C. Camps, "Lactic acid bacteria as biocontrol agents of soil-borne pathogens," Biological Control of Fungal and Bacterial Plant Pathogens, vol. 78, pp. 285-288, 2012.

[49] W. P. Hammes, A. Bantleon, and S. Min, "Lactic acid bacteria in meat fermentation," FEMS Microbiology Reviews, vol. 87, no. 1-2, pp. 165-173, 1990.

[50] O. Kandler, U. Schillinger, and N. Weiss, "Lactobacillus halotolerans sp. nov., nom. rev. and Lactobacillus minor sp. nov., nom. rev," Systematic and Applied Microbiology, vol. 4, no. 2, pp. 280285, 1983.

[51] F. Leroy and L. de Vuyst, "Lactic acid bacteria as functional starter cultures for the food fermentation industry," Trends in Food Science and Technology, vol. 15, no. 2, pp. 67-78, 2004.

[52] N. P. Guerra, A. T. Agrasar, C. L. Macías, P. F. Bernárdez, and L. P. Castro, "Dynamic mathematical models to describe the growth and nisin production by Lactococcus lactis subsp. lactis CECT 539 in both batch and re-alkalized fed-batch cultures," Journal of Food Engineering, vol. 82, no. 2, pp. 103-113, 2007.

[53] L. Chen, G. Wang, S. Hong, A. Liu, C. Li, and Y. Liu, "UV-Binduced oxidative damage and protective role of exopolysaccharides in desert cyanobacterium Microcoleus vaginatus," Journal of Integrative Plant Biology, vol. 51, no. 2, pp. 194-200, 2009.

[54] A. S. Ferreira, I. N. Silva, V. H. Oliveira, R. Cunha, and L. M. Moreira, "Insights into the role of extracellular polysaccharides in Burkholderia adaptation to different environments," Frontiers in Cellular and Infection Microbiology, vol. 1, p. 16, 2011.

[55] A. W. Qurashi and A. N. Sabri, "Osmoadaptation and plant growth promotion by salt tolerant bacteria under salt stress," African Journal of Microbiology Research, vol. 5, no. 21, pp. 35463554, 2011.
[56] H. Abriouel, N. B. Omar, A. C. Molinos et al., "Comparative analysis of genetic diversity and incidence of virulence factors and antibiotic resistance among enterococcal populations from raw fruit and vegetable foods, water and soil, and clinical samples," International Journal of Food Microbiology, vol. 123, no. 1-2, pp. 38-49, 2008.

[57] P. Poeta, D. Costa, J. Rodrigues, and C. Torres, "Antimicrobial resistance and the mechanisms implicated in faecal enterococci from healthy humans, poultry and pets in Portugal," International Journal of Antimicrobial Agents, vol. 27, no. 2, pp. 131-137, 2006.

[58] A. T. Cruz, A. C. Cazacu, and C. H. Allen, "Pantoea agglomerans, a plant pathogen causing human disease," Journal of Clinical Microbiology, vol. 45, no. 6, pp. 1989-1992, 2007.

[59] L. Wjohn, N. Masashi, and M. Kathrin, "Stenotrophomonas maltophilia: an emerging opportunist human pathogen," The Lancet Infectious Diseases, vol. 9, no. 5, pp. 312-323, 2009.

[60] G. Giraffa, D. Carminati, and G. T. Tarelli, "Inhibition of listeria innocua in milk by bacteriocin-producing Enterococcus faecium 7C5," Journal of Food Protection, vol. 58, no. 6, pp. 621-623, 1995.

[61] R. S. Kumar, P. Kanmani, N. Yuvaraj, K. A. Paari, V. Pattukumar, and V. Arul, "Purification and characterization of enterocin MC13 produced by a potential aquaculture probiont Enterococcus faecium MC13 isolated from the gut of Mugil cephalus," Canadian Journal of Microbiology, vol. 57, no. 12, pp. 993-1001, 2011.

[62] A. Ahmadova, S. Dimov, I. Ivanova et al., "Proteolytic activities and safety of use of Enterococci strains isolated from traditional Azerbaijani dairy products," European Food Research and Technology, vol. 233, no. 1, pp. 131-140, 2011.

[63] S. Maisnier-Patin, E. Forni, and J. Richard, "Purification, partial characterisation and mode of action of enterococcin EFS2, an antilisterial bacteriocin, produced by a strain of Enterococcus faecalis isolated from a cheese," International Journal of Food Microbiology, vol. 30, no. 3, pp. 255-270, 1996.

[64] L. Nickelsen and M. Jakobsen, "Quantitative risk analysis of aflatoxin toxicity for the consumers of "kenkey"-a fermented maize product," Food Control, vol. 8, no. 3, pp. 149-159, 1997.

[65] F. Valerio, M. Favilla, P. de Bellis, A. Sisto, S. de Candia, and P. Lavermicocca, "Antifungal activity of strains of lactic acid bacteria isolated from a semolina ecosystem against Penicillium roqueforti, Aspergillus niger and Endomyces fibuliger contaminating bakery products," Systematic and Applied Microbiology, vol. 32, no. 6, pp. 438-448, 2009.

[66] K. W. Lee, J. Y. Park, H. R. Jeong, H. J. Heo, N. S. Han, and J. H. Kim, "Probiotic properties of Weissella strains isolated from human faeces," Anaerobe, vol. 18, no. 1, pp. 96-102, 2012.

[67] G. Berg, A. Fritze, N. Roskot, and K. Smalla, "Evaluation of potential biocontrol rhizobacteria from different host plants of Verticillium dahliae Kleb," Journal of Applied Microbiology, vol. 91, no. 3, pp. 963-971, 2001.

[68] V. Mandal, S. K. Sen, and N. C. Mandal, "Detection, isolation and partial characterization of antifungal compound(s) produced by Pediococcus acidilactici LAB 5," Natural Product Communications, vol. 2, pp. 671-674, 2007.

[69] J. Magnusson, K. Ström, S. Roos, J. Sjögren, and J. Schnürer, "Broad and complex antifungal activity among environmental isolates of lactic acid bacteria," FEMS Microbiology Letters, vol. 219, no. 1, pp. 129-135, 2003. 

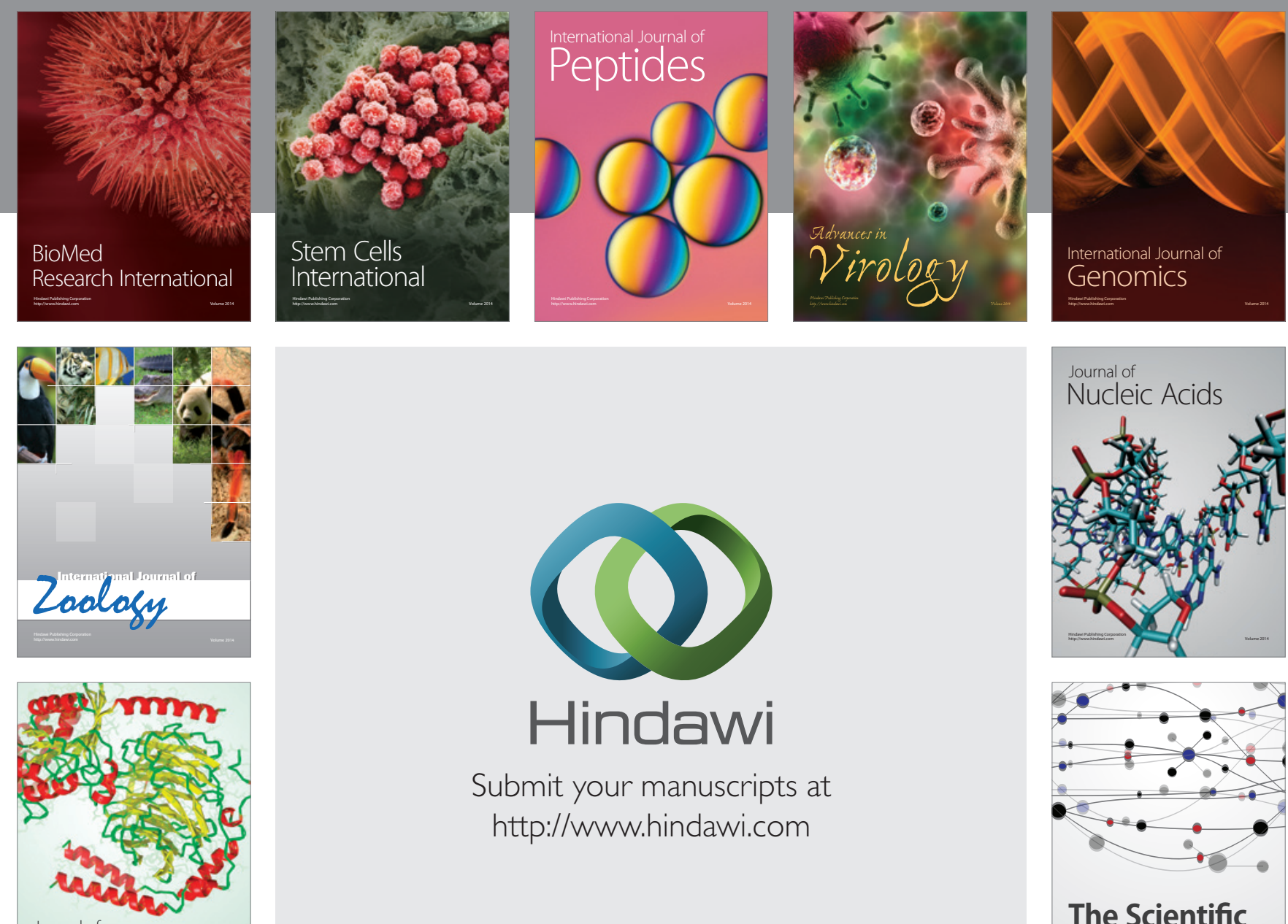

Submit your manuscripts at

http://www.hindawi.com

Journal of
Signal Transduction
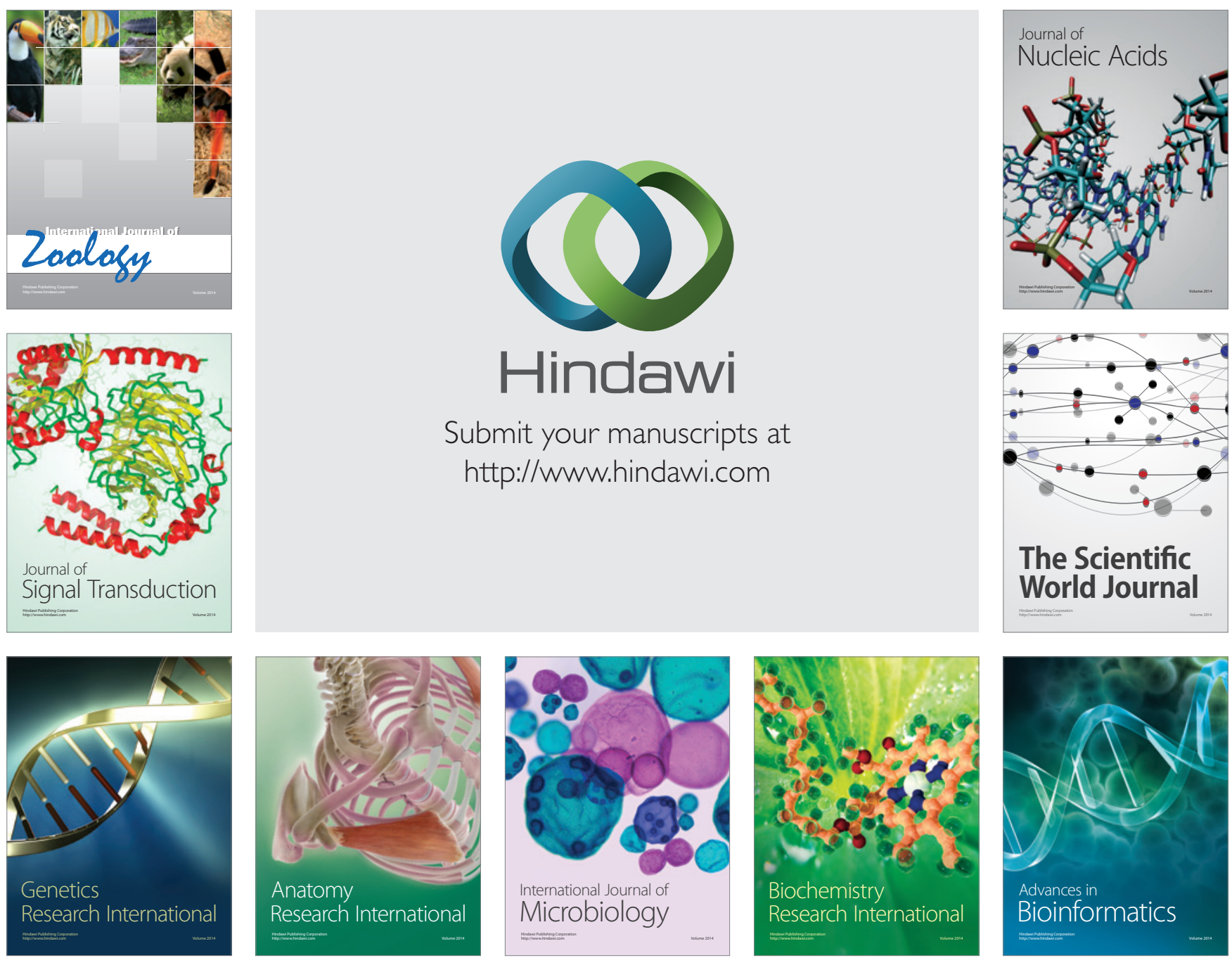

The Scientific World Journal
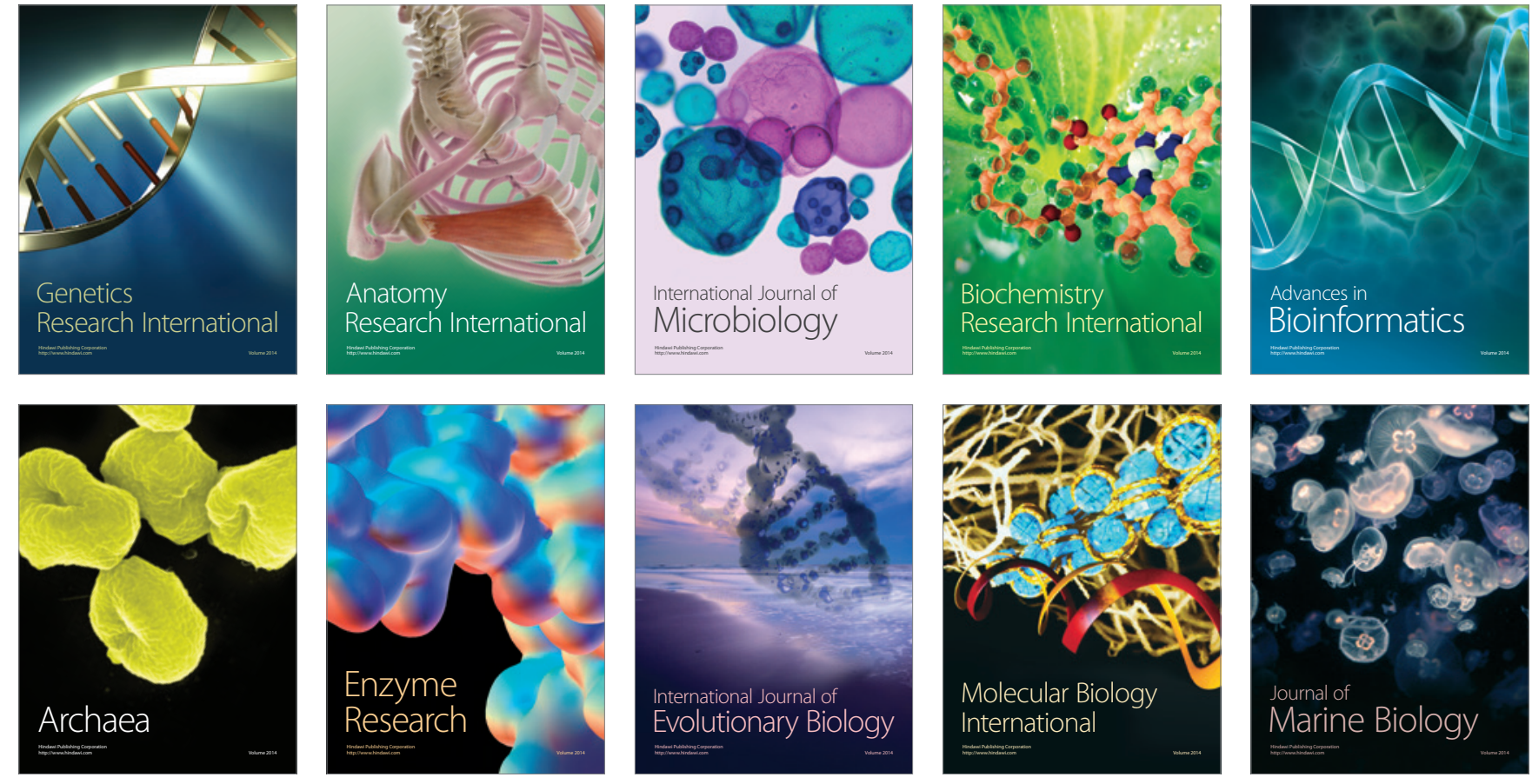